\title{
Pruning Effect on Yield and Fruit Quality in Guava at Eastern Uttar Pradesh Conditions
}

\author{
S. V. Singh* \\ Shri Durga Ji P.G. College, Chandeshwer, Azamgarh (U.P.)-276128, India \\ *Corresponding author
}

\section{A B S T R A C T}

\begin{tabular}{l}
\hline Key w o r d s \\
Pruning, Guava, \\
Fruit quality, Yield \\
\hline Article Info \\
\hline $\begin{array}{l}\text { Accepted: } \\
18 \text { May } 2020 \\
\text { Available Online: } \\
\text { 10 June } 2020\end{array}$ \\
\hline
\end{tabular}

This trial was carried out during 2017-2018 and 2018- 2019 on 12 years old seedy guava (Psidium guajva, L) trees planted at $5 \times 5$ meters at college farm, S.D.J.P.G. collegeChandeshwer, Azamgarh, U.P. This investigation aimed to study the effect of some pruning treatments: 1- Control (unpruned trees). 2- Apical ten $\mathrm{cm}$ of new shoots were pruned. 3- Apical twenty $\mathrm{cm}$ of new shoots were pruned, in three dates: May, June and July on yield and fruit quality of guava trees. The obtained results showed that, number of fruits per tree, yield per tree and fruit weight was better with apical $10 \mathrm{~cm}$ of pruning shoots with May, while fruit set percentage and total sugars were better with apical $10 \mathrm{~cm}$ of pruning shoots at May and June. In the other side, fruit weight and fruit volume gave the highest values with apical $20 \mathrm{~cm}$ of new pruned shoots at May and June, while TSS gave the highest values with apical 10 and twenty $\mathrm{cm}$ of new pruned shoots at May and June, but fruit dry weight percentage gave insignificant differences among treatments in first season, but gave highest results in second season with apical $10 \mathrm{~cm}$ of new pruned shoots at June, whereas maximum Vitamin C was found in control guava fruits at May We can be recommended by apical $10 \mathrm{~cm}$ of pruning shoots at May to get the best results of yield, fruit growth and fruit quality.

\section{Introduction}

Guava is considered as a remunerative fruit; grows well under different range of soil and agro climatic conditions. Its fruit is rich in vitamin C (200-300 mg/100g of pulp). And also have vitamin $A$, riboflavin, thiamine and minerals like calcium, phosphorus and iron. Furthermore, guava is processed commercially into jam, jellies and other products. Inspite of being a popular fruit, meager information is available on suitable planting density for guava. The pruning may be helpful in reducing the tree size and improving the fruit quality as well Haropinder and Bal (2006). Lal (1983) indicated that the yield of guava cv. Sadar was improved by pruning. Pruning and hydrogen Cyanamid were found to modify the production curve of guava Quijada et al., (1999). Also, Salah (2005) produced the highest bud emergence of guava by using severe and moderate pruning. Haropinder and Bal (2006) stated that pruning with $(10$ and $20 \mathrm{~cm})$ and growth regulators (paclobutrazol and ethephon at 500 and $1000 \mathrm{ppm}$ ) treatments on guava cv. 
Allahabad Safeda trees during rainy season planted with four different spacing's $(6 \times 2 \mathrm{~m}$, $6 \times 3 \mathrm{~m}, 6 \times 4 \mathrm{~m}$ and $6 \times 5 \mathrm{~m})$. Maximum fruit size, palatability rating, TSS and vitamin $\mathrm{C}$ were noted in wider spacing $(6 \times 5 \mathrm{~m})$. They found that maximum Vitamin $\mathrm{C}$ was found in control in guava fruits. Physical characters like fruit weight was improved at $20 \mathrm{~cm}$ level of pruning. Whereas, fruit quality (chemical characters) were noted better at $10 \mathrm{~cm}$ level of pruning. The time and intensity of pruning affected guava cv. Paluma tree sprout and yield (Serrano et al., 2008a). Moreover, (Serrano et al. 2008b) reported that the light pruning increased the number of productive branches and number of fruits per branch of guava cv. Paluma. The present study was, carried out to find the effect of some pruning treatments at different time on fruit set, yield and fruit physical and chemical properties in guava.

\section{Materials and Methods}

The trial was conducted t during during 20172018 and 2018- 2019 on 12 years old seedy guava (Psidium guajva, L) trees planted at $5 \times 5$ meters at college farm, S.D.J.P.G. college- Chandeshwer, Azamgarh, U.P. Fifty four trees, uniform in growth and in good physical condition were selected and grouped under three treatments.

\section{Trees under investigation were subjected to} the following treatments

1-Control (unpruned trees). 2-Apical ten $\mathrm{cm}$ of new shoots were pruned. 3- Apical twenty $\mathrm{cm}$ of new shoots were pruned. Pruning treatments were carried out at 15thof May, June and July for both seasons.

The experiment was design in split plot design where pruning in main plot and dates of pruning in sub plot ( 3 pruning treatments $\mathrm{x}$ 3 pruning date $=9$ treatments) in a factorial experiment. Each treatment had three replicates and two trees for each. Data was statistically analyzed according to Snedecor and Cochran (1980). The following measurements were recorded: Fruit and Yield Indices: a) Fruit set percentage: Four branches for each tree of three treatments were selected at random, then tagged and their flowers were counted during the full bloom. Fruitlets were also counted and recorded at the right time of fruit setting in mid-July. Fruit set was calculated as a percentage of the initial number of flowers as follows:

\section{No. of set fruits \\ Fruit set \% = - \\ Total number of opened flowers}

Yield $(\mathrm{Kg})$, at harvest time, mature fruits were picked, tree yield in $\mathrm{Kg}$ was estimated by multiplying number of fruits per tree $\mathrm{x}$ average of fruit weight.

Fruit quality: Fifteen fruits of the same age were labeled at fruit maturity for each tree to study fruit physical and chemical properties at harvest date.

Fruit physical properties: The following physical properties were determined and recorded i.e., fruit weight $(\mathrm{g})$, fruit volume (cm3) and fruit dry weight percentage.

Fruit chemical properties: The following chemical properties were determined: Total soluble solids (T.S.S) were determined with the help of Bausch and Lomb Refractometer in terms of degree Brix. The values of TSS were corrected at $20^{\circ} \mathrm{C}$. Ascorbic acid (Vitamin C) was determined using 2,6dichlorophenol indophenol solutions and oxalic acid as a substrate. Vitamin $\mathrm{C}$ content was calculated as $\mathrm{mg} / 100 \mathrm{ml}$ juice and total sugars content were determined calorimetrically according to A.O.A.C, (1980). The total sugar contents were 
determined colorimetrically by using picric acid Thomas and Ditcher (1924) and expressed as $\mathrm{g} / 100 \mathrm{~g}$ fresh weight.

\section{Results and Discussion}

Data in table (1) Effect of pruning treatments, date and their interaction on fruit set\%, number of fruits /tree and yield $(\mathrm{Kg})$ in guava trees during (2010/2011) seasons. Fruit set\%: concerning to pruning treatments, pruning at $10 \mathrm{~cm}$ gave highest significant value in both seasons. Regarding to date, May and June gave higher significant values than July in both seasons. The interaction between two studies factors, pruning at $20 \mathrm{~cm}$ with May and June gave highest significant values in first and second seasons. No. of fruits /tree: concerning to pruning treatments, pruning at $10 \mathrm{~cm}$ gave highest significant value in both seasons. Regarding to date, pruning at May gave highest significant value in both seasons. The interaction between two studies factors, pruning at $10 \mathrm{~cm}$ with May pruning gave highest significant values in first and second seasons.

Yield (Kg) /tree: concerning to pruning treatments, pruning at $10 \mathrm{~cm}$ gave highest significant value in both seasons. Regarding to date, pruning at May gave highest significant value in both seasons. The interaction between two studies factors, pruning at $10 \mathrm{~cm}$ with May pruning gave highest significant value in first and second seasons. These results agreement with Shaban and Haseeb (2009)they found that moderate pruning and treatments at 15th February on 25 years guava trees hybrid I apronounced and significant increase in initial fruit set, also pruning treatments with spraying chemicals substances improved tree yield. Data in table (2) Effect of pruning treatments, date and their interaction on fruit weight $(\mathrm{g})$, fruit volume $\left(\mathrm{cm}^{3}\right)$ and fruit dry weight percentage of guava trees during (2010/2011) seasons.
Fruit weight (g): concerning to pruning treatments, pruning at $20 \mathrm{~cm}$ gave highest significant value. Regarding to date, pruning at May gave highest significant value. The interaction between two studies factors, pruning at $10 \mathrm{~cm}$ with May and pruning at 20 $\mathrm{cm}$ with May and June gave highest significant values in first season. In second season, concerning to pruning treatments, pruning at $20 \mathrm{~cm}$ gave highest significant fruit weight. Regarding date of pruning both May and June pruning gave higher significant values than July. The interaction between two studies factors, pruning at $20 \mathrm{~cm}$ at May and June had highest significant values.

Fruit volume $\left(\mathrm{cm}^{3}\right)$ : concerning to pruning treatments, pruning at $20 \mathrm{~cm}$ gave highest significant value in both seasons. Regarding to date, pruning at May gave highest significant values in both seasons. The interaction between two studies factors, pruning at $20 \mathrm{~cm}$ with May and June pruning gave highest significant values in first season, while pruning at $20 \mathrm{~cm}$ with May pruning gave highest significant value in second season. Fruit dry weight (g): concerning to pruning treatments, there were insignificant differences among all treatments. Regarding to date, pruning at June gave highest significant value. The interaction between two studies factors, there are insignificant differences among treatments in first season, except pruning $10 \mathrm{~cm}$ with June showed higher significant value than pruning $10 \mathrm{~cm}$ with May. In the second season, concerning to pruning treatments, pruning at $20 \mathrm{~cm}$ gave highest significant value. Regarding to date, pruning at June gave highest significant value. The interaction between two studies factors, pruning at $10 \mathrm{~cm}$ with June gave highest significant value. These results agreement with Haropinder and Bal (2006) they found that physical characters like fruit weight was improved at $20 \mathrm{~cm}$ level of pruning in guava fruits. 
Table.1 Effect of pruning treatments, date and their interaction on fruit set percentage, number of fruits /tree and yield of guava trees during (2018-2019) seasons

\begin{tabular}{|c|c|c|c|c|c|c|c|c|c|c|c|c|}
\hline \multirow[t]{3}{*}{ Treatments } & \multicolumn{5}{|c|}{ Fruit set \% } & \multicolumn{4}{|c|}{ No. of fruits/tree } & \multicolumn{3}{|c|}{ Yield (Kg) /tree } \\
\hline & \multicolumn{12}{|c|}{ First season } \\
\hline & May & June & July & Mean & May & June & July & Mean & May & June & July & Mean \\
\hline Control & $0.52 b$ & $0.51 b$ & $0.42 b$ & $0.50 \mathrm{~B}^{\prime}$ & $242.6 \mathrm{~d}$ & $281.0 \mathrm{e}$ & $96.0 \mathrm{i}$ & 206.41B' & $24.21 \mathrm{~d}$ & $24.58 \mathrm{c}$ & $7.89 \mathrm{j}$ & 19.34B' \\
\hline Pruning $10 \mathrm{~cm}$ & $0.71 \mathrm{a}$ & $0.61 \mathrm{a}$ & $0.42 b$ & $0.60 \mathrm{~A}^{\prime}$ & $307.0 \mathrm{a}$ & $274.0 \mathrm{c}$ & $172.0 \mathrm{i}$ & $251.0 \mathrm{~A}^{\prime}$ & $31.45 \mathrm{a}$ & $27.21 b$ & $16.42 \mathrm{a}$ & $25.21 \mathrm{~A}^{\prime}$ \\
\hline Pruning $20 \mathrm{~cm}$ & $0.45 b$ & $0.42 b$ & $0.41 b$ & $0.44 C^{\prime}$ & $166.0 f$ & $139.0 \mathrm{~h}$ & $150.0 \mathrm{j}$ & $152.0 \mathrm{C}^{\prime}$ & $17.25 \mathrm{a}$ & $14.36 f$ & $14.67 f$ & $15.11 \mathrm{C}^{\prime}$ \\
\hline Mean & $0.56 \mathrm{~A}$ & $0.52 \mathrm{~A}$ & $0.42 \mathrm{~B}$ & & $\begin{array}{l}239.3 \\
\text { A }\end{array}$ & $\begin{array}{l}230.23 \\
\text { B }\end{array}$ & $142.66 \mathrm{C}$ & & $24.67 \mathrm{~A}$ & $22.57 \mathrm{~B}$ & $12.89 \mathrm{C}$ & \\
\hline \multicolumn{13}{|c|}{ Second season } \\
\hline & May & June & July & Mean & May & June & July & Mean & May & June & July & Mean \\
\hline Control & $0.51 b$ & $0.56 b$ & $0.41 b$ & $0.51 \mathrm{~B}^{\prime}$ & $281.7 \mathrm{c}$ & $182.2 \mathrm{a}$ & $98.0 \mathrm{i}$ & 187.5B' & 26.1c & $19.29 \mathrm{e}$ & $7.21 \mathrm{j}$ & $17.43 C^{\prime}$ \\
\hline Pruning $10 \mathrm{~cm}$ & $0.72 \mathrm{a}$ & $0.62 \mathrm{a}$ & $0.41 b$ & $0.60 A^{\prime}$ & $311.6 \mathrm{a}$ & $276.4 b$ & $155.0 \mathrm{j}$ & $251.6 A^{\prime}$ & $33.9 \mathrm{a}$ & $28.5 b$ & $16.21 \mathrm{e}$ & $25.21 \mathrm{~A}$ \\
\hline Pruning $20 \mathrm{~cm}$ & $0.44 b$ & $0.41 b$ & $0.44 b$ & $0.41 \mathrm{~B}^{\prime}$ & $224.1 d$ & 149.h & $177.2 \mathrm{f}$ & $180.7 C^{\prime}$ & $24.74 d$ & $15.3 \mathrm{j}$ & $14.93 f$ & 19.0B' \\
\hline Mean & $\begin{array}{l}0.58 \\
\text { A }\end{array}$ & $0.52 \mathrm{~A}$ & $0.42 \mathrm{~B}$ & & $\begin{array}{l}271.6 \\
\text { A }\end{array}$ & 201.B & 141.1C & & $28.89 \mathrm{~A}$ & 21.33B & $12.67 \mathrm{C}$ & \\
\hline
\end{tabular}

Means having the same letter (s) in each row, column or interaction are insignificantly different at $5 \%$ level. 
Table.2 Effect of pruning treatments, date and their interaction on: fruit weight $(\mathrm{g})$, fruit volume $\left(\mathrm{cm}^{3}\right)$ and fruit dry weight $\%$ in guava trees during (2018-2019) seasons

\begin{tabular}{|c|c|c|c|c|c|c|c|c|c|c|c|c|}
\hline \multirow[t]{3}{*}{ Treatments } & \multicolumn{4}{|c|}{ Fruit weight (g) } & \multicolumn{4}{|c|}{ Fruits volume $\left(\mathrm{cm}^{3}\right)$} & \multicolumn{4}{|c|}{ Dry fruit weight (\%) } \\
\hline & \multicolumn{12}{|c|}{ First season } \\
\hline & May & June & July & Mean & May & June & July & Mean & May & June & July & Mean \\
\hline Control & $99.21 \mathrm{~b}$ & $93.22 b$ & 86.22 & 92.22 C' & $100 \mathrm{~b}$ & $97.34 b$ & $80.01 \mathrm{c}$ & 92.45C' & $5.11 \mathrm{ab}$ & $6.01 \mathrm{ab}$ & $5.99 \mathrm{ab}$ & 5.88A' \\
\hline Pruning $10 \mathrm{~cm}$ & $107.24 \mathrm{a}$ & 102.34 & 101.23 & 102.09B' & $101.2 b$ & $97.01 b$ & $98.09 b$ & 98.76B' & $5.14 b$ & $7.21 \mathrm{a}$ & $6.01 \mathrm{ab}$ & 5.99A' \\
\hline Pruning $20 \mathrm{~cm}$ & 108.64 & 108.61 & 98.68 & 104.21A' & $113.67 \mathrm{a}$ & $112 \mathrm{a}$ & $97.23 b$ & 107.21A' & $6.02 \mathrm{~B}$ & $6.21 \mathrm{ab}$ & $5.34 \mathrm{ab}$ & $6.22 \mathrm{~A}^{\prime}$ \\
\hline Mean & 106.09A & 101.07 & 95.06 & & 105.1A & 102.21B & 92.02C & & 5.04 B & $6.24 \mathrm{~A}$ & 5.11B & \\
\hline \multicolumn{13}{|c|}{ Second season } \\
\hline & May & June & July & Mean & May & June & July & Mean & May & June & July & Mean \\
\hline Control & $95.36 \mathrm{j}$ & $107.68 \mathrm{c}$ & $89.67 \mathrm{~h}$ & 98.21C' & 108.d & $97.06 \mathrm{~h}$ & $94.2 \mathrm{i}$ & $100 C^{\prime}$ & $5.11 \mathrm{~d}$ & $6.12 b$ & $5.21 \mathrm{c}$ & 5.21B' \\
\hline Pruning $10 \mathrm{~cm}$ & $110.86 b$ & $102.80 \mathrm{e}$ & $104.8 d$ & 105.87B' & $112.7 \mathrm{c}$ & $106 \mathrm{e}$ & $99.67 j$ & 105.43B' & $4.98 \mathrm{~d}$ & $6.97 a$ & $5.06 \mathrm{~d}$ & 5.21B' \\
\hline Pruning $20 \mathrm{~cm}$ & $112.43 a$ & $112.78 \mathrm{a}$ & $100.9 f$ & 108.7A' & $115.34 \mathrm{a}$ & $114.3 \mathrm{~b}$ & $101.85 f$ & 110.4A' & $6.02 b$ & $6.11 b$ & $5.28 c$ & 6.02A' \\
\hline Mean & 107.87A & 107.97A & 98.75B & & 112.76 $A^{\prime}$ & 105.9B & 98.5C & & $5.02 B$ & $6.18 \mathrm{~A}$ & 5.07B & \\
\hline
\end{tabular}

Means having the same letter (s) in each row, column or interaction are insignificantly different at $5 \%$ level. 
Table.3 Effect of pruning treatments, date and their interaction on TSS\%, total sugars\% and vitamin C $\mathrm{mg} / 100 \mathrm{ml}$ in guava trees during (2018-2019) seasons

\begin{tabular}{|c|c|c|c|c|c|c|c|c|c|c|c|c|}
\hline \multirow{3}{*}{$\begin{array}{c}\text { Treatmen } \\
\text { ts }\end{array}$} & \multicolumn{4}{|c|}{ TSS (\%) } & \multicolumn{4}{|c|}{ Total sugar (\%) } & \multicolumn{4}{|c|}{ Vitamin C mg/100ml } \\
\hline & \multicolumn{12}{|c|}{ First season } \\
\hline & May & June & July & Mean & May & June & July & Mean & May & June & July & Mean \\
\hline Control & $6.87 b$ & $7.01 \mathrm{~b}$ & $7.11 \mathrm{~b}$ & 7.02C' & $4.87 \mathrm{c}$ & $5.01 \mathrm{c}$ & $4.21 \mathrm{c}$ & 5.02C' & $88.32 \mathrm{a}$ & $84.89 b$ & $80.07 \mathrm{c}$ & 84.11A' \\
\hline $\begin{array}{l}\text { Pruning } \\
10 \mathrm{~cm}\end{array}$ & $10.01 \mathrm{a}$ & $9.20 \mathrm{a}$ & $7.08 \mathrm{~b}$ & 9.05B' & $7.01 \mathrm{a}$ & $6.80 \mathrm{a}$ & $4.26 \mathrm{a}$ & 6.07A' & $71.76 \mathrm{~d}$ & $69.08 \mathrm{e}$ & $59.78 \mathrm{~h}$ & 66.31B' \\
\hline $\begin{array}{l}\text { Pruning } \\
20 \mathrm{~cm}\end{array}$ & $8.87 \mathrm{a}$ & $8.23 \mathrm{a}$ & $5.45 \mathrm{c}$ & 7.21B' & $5.67 b$ & $5.79 b$ & $4.19 b$ & 5.26B' & $65.21 \mathrm{f}$ & $62.28 \mathrm{j}$ & $65.77 f$ & 64.76C' \\
\hline Mean & 8.01A & 7.89A & 6.57B & & $6.02 \mathrm{~A}$ & $6.05 \mathrm{~A}$ & 4.27B & & 75.09A & 72.46B & 67.03C & \\
\hline \multicolumn{13}{|c|}{ Second season } \\
\hline & May & June & July & Mean & May & June & July & Mean & May & June & July & Mean \\
\hline Control & $8.12 \mathrm{a}$ & $7.21 \mathrm{~b}$ & $7.99 \mathrm{~b}$ & 7.87B' & $5.04 \mathrm{c}$ & $5.01 \mathrm{c}$ & $4.28 \mathrm{~d}$ & 5.09C' & $88.47 \mathrm{a}$ & $84.96 b$ & $84.27 b$ & 86.11A \\
\hline $\begin{array}{l}\text { Pruning } \\
10 \mathrm{~cm}\end{array}$ & $10.41 \mathrm{a}$ & $9.02 \mathrm{a}$ & $6.89 b$ & 8.78A, & $6.38 \mathrm{a}$ & $7.06 \mathrm{a}$ & $4.11 \mathrm{~d}$ & $5.88 A^{\prime}$ & $74.32 c$ & $68.87 \mathrm{e}$ & $70.88 d$ & 70.28B' \\
\hline $\begin{array}{l}\text { Pruning } \\
20 \mathrm{~cm}\end{array}$ & $9.54 \mathrm{a}$ & $7.76 b$ & $7.54 b$ & 8.42B' & $5.78 b$ & $5.76 b$ & $4.90 \mathrm{~d}$ & 5.34B' & $57.67 j$ & $55.98 \mathrm{~h}$ & $60.81 f$ & 58.23C' \\
\hline Mean & $9.41 \mathrm{~A}$ & 8.01B & 7.05B & & & $5.83 \mathrm{~A}$ & $5.92 A$ & 4.24B & 73.82A & 69.02C & 72.95B & \\
\hline
\end{tabular}

Means having the same letter (s) in each row, column or interaction are insignificantly different at $5 \%$ level. 
TSS\%: concerning to pruning treatments, pruning at $10 \mathrm{~cm}$ gave highest significant value. Regarding to date, pruning at May and June recorded highest significant values. The interaction between two studies factors, pruning at $10 \mathrm{~cm}$ and $20 \mathrm{~cm}$ with May and June showed highest significant values in first season. In second season, concerning to pruning treatments, pruning at $10 \mathrm{~cm}$ recorded highest significant value. Regarding to date, pruning at May showed highest significant TSS value. The interaction between two studied factors, all pruning treatments with May and pruning $10 \mathrm{~cm}$ with June had highest significant values. Total sugars\%: concerning to pruning treatments, pruning at $10 \mathrm{~cm}$ gave highest significant value in both seasons. Regarding to date, pruning at May and June gave highest significant values in both seasons. The interaction between two studies factors, pruning at $10 \mathrm{~cm}$ with May and June pruning gave highest significant values in both seasons. Vitamin C: concerning to pruning treatments, control gave highest significant value in both seasons. Regarding to date, pruning at May gave highest significant value in both seasons. The interaction between two studies factors, control with May recorded highest significant values in both seasons. These results agreement with Haropinder and Bal (2006) they found that guava fruits which pruning at 10 and $20 \mathrm{~cm}$ and growth regulators (paclobutrazol and ethephon at 500 and 1000 ppm), maximum Vitamin $\mathrm{C}$ was found in control and fruit quality (chemical characters) were noted better at $10 \mathrm{~cm}$ level of pruning.

\section{References}

A.O.A.C. (1990). Association of official Agricultural chemists. Official Methods of Analysis, Washington, D.C., U.S.A. Apple. Arch. Gartenban, 23. (8):483-489.

Haropinder Jit Singh and J. S. Bal (2006). Effect of pruning and growth regulators on physio-chemical characters of guava during rainy season planted at different spacing. Internat. J. agric. Sci. Vol. 2 No.2: (533-537).

Lal, S.(1983). Effect of pruning on crop regulation in guava (Psidium guajava L.) cv. Lucknow-49. Prog. Hort., 7(3): 60-62.

Salah, A. El-D.M.(2005). Effect of pruning on growth, flowering and fruiting of some guava cultivars. M.Sc. Thesis, Fac. Agric. Cairo Univ.

Serrano, L.A.L; C.S. Marinho; E. Gabetto, M. Silva and F.D.Tardin (2008a). Phenological and yield characteristics of "Paluma" guava tree pruned in different times and intensities, in north of Rio de Janeiro State, Brazil. Revista Ceres, 55(5): 416-424.

Serrano, L.A.L; M.V.V. Martins; I. De M. Lima; C.S. Marinho and F.D. Tardin (2008b). Effect of pruning time and intensity on Paluma' guava trees, in Pinheiros, ES, Brazil. Revista Brasileira de Fruticultura, 30(4): 994-1000.

Shaban, A.E.A.; and G.M.M. Haseeb (2009). Effect of pruning severity and some chemical substances on growth and fruiting of guava trees. AmericanEurasian J. Agric. \& Environ. Sci; 5(6): 825-831.

Snedecor, G.W. and W.G. Cochran (1980). Statical methods. 6th Ed lowa state univ. press, Ames. Lowa.

Tomas, W. and R.A. Dutcher (1924) .The colourimetric determination of CHOin plants by the picric acid reduction methods. J. Amer. Chem., Soc., 46:7-12.

Quijada, O; F. Araujo and P. Corzo (1999). Effect of pruning and hydrogen cyanamide on bud break, flowering, fruit yield and quality of guava (Psidium guajava L.) in the municipality of Mara, state of Zulia. Revista de la Facultad de Agronomia, Universidad del Zulia., 16(3): 276-291. 


\section{How to cite this article:}

Singh, S. V. 2020. Pruning Effect on Yield and Fruit Quality in Guava at Eastern Uttar Pradesh Conditions. Int.J.Curr.Microbiol.App.Sci. 9(06): 1045-1052. doi: https://doi.org/10.20546/ijcmas.2020.906.130 